\title{
PENERAPAN APLIKASI QUIZIZZ DALAM PEMBELAJARAN DARING DI ERA COVID-19
}

\author{
Nunung Supriadi, Destyanisa Tazkiyah, Zuyinatul Isro \\ Fakultas Ilmu Budaya \\ Universitas Jenderal Soedirman
}

\begin{abstract}
Abstrak
Kegiatan belajar secara daring mulai ditetapkan pemerintah sejak bulan Maret 2020 karena adanya virus Covid-19 yang menyerang dunia. Kebijakan ini dilakukan pemerintah untuk menghindari penyebaran Covid-19. Dengan adanya kebijakan tersebut maka terdapat perubahan metode dalam penyampaian materi yang harus digunakan oleh para pengajar. Pembelajaran dengan menggunakan teknologi saat ini melalui daring selaras dengan penggunaan E-Learning pada era 4.0. Pada penerapan pembelajaran secara daring ini masih mengalami kendala terutama pada antusias mahasiswa untuk belajar mengalami penurunan. Untuk mengatasi kendala ini, salah satu cara yang menarik dan menumbuhkan semangat mahasiswa pembelajaran yang dilakukan yaitu menggunakan aplikasi Quizizz. Aplikasi Quizizz ini merupakan media pembelajaran online (ELearning) yang memiliki fitur game, kuis, diskusi, dan survei. Penelitian ini mengkaji tentang aplikasi Quizizz yang memiliki manfaat sebagai media pembelajaran yang efektif guna meningkatkan penguasaan dan motivasi mahasiswa dalam belajar bahasa Mandarin secara daring dengan tidak menghilangkan kearifan lokal Banyumas. Peneliti bermaksud mendesain kuis dengan menerapkan ke sekolah-sekolah di Purwokerto yang memiliki pelajaran bahasa Mandarin. Pengumpulan data penelitian ini menggunakan teknik observasi, wawancara, dan penilaian kuis pada aplikasi Quizizz. Hasil penelitian pembelajaran Quizizz proses pembelajaran menjadi mudah, menyenangkan dan bisa membantu siswa untuk memahami bahasa Mandarin. Selain itu, pembelajaran dengan menerapkan teknik bermain menggunakan aplikasi Quizizz sangat tepat bagi pembelajar pemula bahasa Mandarin.
\end{abstract}

Kata Kunci : quizizz, e-learning, pembelajaran bahasa Mandarin

\section{A. PENDAHULUAN}

Saat ini dunia mengalami serangan virus yang menyerang di seluruh negara salah satunya negara tercinta kita Indonesia. Virus ini terkenal dengan nama Covid-19, datangnya virus ini menyebabkan lockdown di seluruh dunia guna menghentikan penyebaran virus. Masa pandemi ini banyak yang mengalami kerugian besar, dalam dunia pendidikan pembelajaran tatap muka menjadi momok menakutkan bagi pengajar maupun siswa. Mengatasi masalah tersebut, pembelajaran tatap muka beralih menjadi daring/online. Tentunya ini membutuhkan teknologi yang modern, karena teknologi menjadi satu-satunya alat dan fasilitas terbaik yang mendukung proses kegiatan belajar mengajar untuk saat ini agar proses pembelajaran tetap berjalan, ternyata walaupun materi disampaikan secara online para siswa tetap termotivasi untuk belajar. Teknologi pendidikan yang inovatif telah terbukti memberikan kesempatan bagi peserta didik untuk terlibat dan memperoleh keterampilan, pengetahuan, dan nilai-nilai penting.

Kompetensi dalam pembelajaran bahasa Mandarin yang disampaikan para siswa untuk bisa dikuasai adalah kemampuan menulis, menbaca, mendengar, dan berbicara. Kegiatan belajar mengajar pada umumnya ditunjang dengan media buku, penyampaian materi dari pengajar, dan mengerjakan latihan-latihan secara tertulis ataupun lisan. Metode pembelajaran seperti ini tergolong sangat ketinggalan jaman dan bersifat monoton, 
sehingga membuat berkurangnya motivasi untuk belajar para siswa. Dengan adanya perkembangan teknologi dan internet sebagai tenaga pendidik sudah sewajarnya memanfaatkan aplikasi-aplikasi pembelajaran online berbasis teknologi, salah satunya adalah aplikasi Quizizz.

Aplikasi Quizizz merupakan media pembelajaran online E-lerning yang berbasis permainan tidak berbayar, digunakan dalam kegiatan belajar mengajar dalam rangka meningkatkan semangat dan memberikan motivasi serta hasil dari proses belajar siswa, untuk merangsang minat siswa mengulang kembali materi pelajaran dan melakukan diskusi secara kelompok. Aplikasi Quizizz menurut Mei Yan (2018) mampu meningkatkan hasil belajar dan motivasi peserta didik. Untuk mendukung semua ini, sekolah menyediakan fasilitas proyektor dan LCD di setiap kelas, jaringan Wi-fi yang bisa diakses siswa dan guru, selain itu siswa juga memiliki smartphone. Dengan adanya fasilitas ini peneliti memanfaatkan aplikasi Quizizz untuk menunjang kegiatan belajar bahasa Mandarin dengan merancang model kuis bahasa Mandarin berbasis kearifan lokal.

Quizizz adalah laman edukatif online yang tersedia di aplikasi PlayStore berbasis android, secara resmi laman Quizizz dipublikasi pada tahun 2017 (Official Website "Quizizz!", 2017). Sampai saat ini pengguna atau pengajar yang terdaftar pada laman Quizizz mencapai 20 juta user, dan peserta didik yang memainkan permainan ini mencapai sekitar 100 juta siswa. Dengan jaringan internet dosen dan mahasiswa bisa mengakses laman Quizizz dari komputer dan smartphone di mana pun dan kapan pun secara gratis, termasuk semua fiturfitur canggih yang tersedia. Pembelajaran berbasis teknologi menurut Arsyad (2013) seperti komputer yang mampu merangsang siswa untuk belajar dan mengerjakan latihan dikarenakan terdapatnya berbagai animasi, ilustrasi grafik, dan warna yang dapat menambah realisme. Quizizz bisa menjadi sarana pendukung kegiatan belajar mengajar yang relevan, baik di tingat sekolah menengah maupun perguruan tinggi. Laman Quizizz memiliki dua alamat website yaitu https:/Quizizz.com/ yang dikhususkan untuk pengajar sebagai tempat untuk merancang kuis online, diskusi, ataupun survei. Sedangkan alamat https://Quizizz.it/ adalah laman yang digunakan peserta didik untuk mengikuti game-basedlearning, perangkat Quizizz dapat diunduh dengan mudah pada smartphone masing-masing.

Penelitian ini terfokus pada pemanfaatan kuis online pada laman Quizizz, cara menggunakan Quizizz sebagai media pembelajaran ataupun evaluasi sangatlah mudah. Sebelum menggunakan aplikasi ini, pengajar membuat akun terlebih dahulu, setelah membuat akun pada laman Quizizz, ia dapat merancang kuis online dengan memanfaatkan fitur-fitur yang ada. Setelah itu, siswa diarahkan untuk masuk ke jaringan internet dan mengakses laman Quizizz it saat kegiatan pembelajaran berlangsung. Kemudian siswa harus memasukan pin dan nama melalui smartphone masing-masing terlebih dahulu. Jika sudah maka siswa akan terhubung dengan perangkat yang terdapat di komputer pengajar yang juga ditampilkan di layar LCD. Perangkat utama pengajar akan menampilkan pertanyaanpertanyaan dari kuis yang sudah dirancang, siswa dapat memilih jawaban yang sesuai dari smartphone mereka dengan durasi waktu yang telah ditentukan. Siswa yang berhasil menjawab dengan benar dengan waktu paling cepat akan mendapatkan nilai yang lebih tinggi. Di akhir kuis pengajar dapat menyimpan hasil perolehan nilai setiap siswa dengan cara mengunduhnya ke komputer atau menyimpannya di Google drive.

Laman Quizizz adalah inovasi teknologi yang membuat pembelajaran menjadi interaktif dan menarik, serta membantu pengajar membuat evaluasi penilaian terhadap peserta didik. Quizizz merupakan salah satu alternatif pilihan dari berbagai macam multimedia 
pembelajaran online yang membuat kegiatan belajar mengajar menjadi menyenangkan dan tidak membosankan, karena perangkat ini mengutamakan gaya belajar yang melibatkan hubungan peran aktif peserta didik dengan teman-temannya secara kompetitif terhadap pembelajaran yang sedang atau telah dipelajari (Sanga Lamsari, 2019). Selain itu, model kuis online pada laman Quizizz dalam kemampuan berkompetisi dan berkolaborasi dapat mempengaruhi perkembangan sosial emosional anak (Wahyu dkk, 2018).

Penggunaan media Quizizz selain membantu siswa mengingat kembali materi yang telah diberikan juga dapat memunculkan kompetisi di antara para siswa sehingga mereka tertantang untuk menjadi yang terbaik di kelas (Irma, 2018). Nilai yang diperoleh siswa akan ditampilkan pada layar LCD setelah menjawab setiap soal, hal ini mampu mendorong semangat siswa saling berkompetisi untuk mendapatkan nilai sebaik mungkin. Kuis online Quizizz tidak hanya menyediakan model permainan individu tetapi juga menyediakan model permainan berkelompok. Dengan model berkelompok siswa dapat saling berdiskusi dan berkolaborasi untuk menjawab soal-soal kuis online.

Pembelajaran daring menggunakan media daring sebagai bentuk pemanfaatan teknologi yang mempermudah pengajar maupun peserta didik dalam mengelola, menyampaikan informasi serta memberikan pengalaman belajar yang berbeda dan tidak monoton (Nurseto, 2011). Media pembelajaran interaktif berbasis teknologi dapat membangkitkan keinginan dan minat baru, meningkatkan motivasi dan rangsangan kegiatan belajar, dan bahkan berpengaruh secara psikologis terhadap siswa. Game education (permainan edukatif) merupakan pembelajaran dengan memusatkan pada sebuah permainan yang di dalamnya terkandung unsur mendidik atau nilai-nilai pendidikan. Game-based-learning atau pembelajaran berbasis teknologi digital melibatkan peserta didik, pada permainanannya peserta didik memiliki keinginan yang lebih besar dalam melanjutkan proses pembelajaran berikutnya dibandingkan dengan pembelajaran yang bersifat konvensional (Sutirna, 2018).

Melalui aplikasi Quizizz peneliti mampu merancang model kuis interaktif yang mencakup tiga kompetensi dasar bahasa Mandarin, yaitu menulis, membaca, juga mendengarkan. Pengajar bisa merancang model kuis sesuai kebutuhan setelah mendaftar pada laman sebagai pengguna. Pengguna bisa menambahkan gambar pada soal kuis, menambahkan video atau rekaman suara percakapan, mengatur lamanya waktu untuk menjawab soal, dan sebagainya. Setelah kuis selesai dilaksanakan pengguna bisa mengunduh hasil penilaian yang direkap otomatis dalam bentuk spreetsheet Microsoft excel.

Adanya kemudahan pengguna untuk merancang model kuis sesuai dengan kebutuhannya dapat dimanfaatkan untuk memasukkan materi kearifan lokal daerah Banyumas ke dalam pembelajaran bahasa Mandarin. Mayoritas buku ajar bahasa Mandarin hanya mencakup kebudayaan Tiongkok saja, namun melalui aplikasi Quizizz pengajar bisa merancang bahan ajar bahasa Mandarin berbasis kearifan lokal, mengangkat kebudayaankebudayaan lokal sebagai penunjang pembelajaran lintas budaya. Selain mampu menciptakaan suasana belajar interaktif yang menarik dan menyenangkan, pemanfaatan aplikasi Quizizz juga dapat meningkatkan minat dan motivasi siswa dalam belajar serta memudahkan mereka dalam memahami materi yang disampaikan.

\section{B. METODE PENELITIAN}

Penelitian ini merupakan penelitian deskriptif kualitatif, kemudian data yang dikumpulkan bersumber dari data primer dan sekunder. Teknik pengumpulan data menggunakan teknik observasi, wawancara, dan dokumentasi. Data penelitian kemudian dikumpulkan selama kegiatan pembelajaran bahasa Mandarin masih berlangsung. 
Wawancara dengan narasumber dilakukan kepada responden dengan metode sampling, yaitu mengambil sampel dari populasi siswa dari sekolah di daerah Purwokerto yang memiliki mata pelajaran bahasa Mandarin. Teknik observasi dilakukan pada saat kegiatan pembelajaran berlangsung saat itu juga hasil penilaian belajar siswa dilaksanakan dengan penggunaan kuis Quizizz bahasa Mandarin berbasis kearifan lokal.

Metode yang digunakan dalam penelitian ini adalah metode simak dari Sudaryanto (1993), beliau menjelaskan bahwa metode simak merupakan metode yang dilakukan dengan cara menyimak penggunaan bahasa. Pada penelitian ini adalah menyimak kuis dan kegiatan kuliah dengan kompetensi dasar kemampuan membaca, menulis, dan mendengarkan. Menurut Marshall dan Rossman (dalam Kabalmay, 2002) proses analisis data kualitatif terdapat beberapa tahapan yaitu; 1) Mengorganisasikan data, 2) Pengelompokan berdasarkan kategori, tema, dan pola jawaban, 3) Menguji asumsi atau permasalahan yang ada terhadap data, 4) Mencari alternatif penjelasan bagi data, 5) Menulis hasil penelitian.

\section{PEMBAHASAN}

\section{Model kuis bahasa Mandarin pada aplikasi Quizizz}

Sebelum dilakukan penelitian, tim peneliti terlebih dahulu melakukan tahapan persiapan guna mendukung proses penelitian. Persiapan difokuskan pada perancangan model kuis Quizizz berbahasa Mandarin yang akan diterapkan dalam kegiatan belajar mengajar. Selain itu, tim peneliti juga melakukan persiapan dalam memilih materi ajar yang akan dituangkan dalam model kuis online Quizizz berbahasa Mandarin yang diambil dari materi pelajaran Mandarin Buku Hanyu Jiaocheng Xia bab 16-30 sesuai dengan materi yang diberikan oleh guru pengajar bahasa Mandarin di sekolah Nasional 3 Bahasa Putera Harapan Purwkerto. Kedua langkah ini adalah langkah utama dalam persiapan penelitian, disamping itu tim juga melakukan persiapan wawancara dengan narasumber yaitu kepala sekolah SMP/SMA Nasional 3 Bahasa Putera Harapan Purwoketo, penanggung jawab bahasa Mandarin, dan pengajar bahasa Mandarin, serta pengambilan data dari siswa-siswa sebagai responden melalui google form dan video.

Model kuis yang dirancang begitu beragam dan tentunya menarik, karena di dalamnya terdapat penjelasan yang cukup rinci dari setiap soal dan jawaban sehingga memudahkan siswa untuk mengingat kembali materi yang telah diajarkan. Dengan metode pembelajaran berbasis permainan seperti Quizizz sangatlah sesuai dengan pembelajaran daring yang diterapkan guna membuat suasana belajar menjadi lebih mudah dan menyenangkan di SMP/SMA Nasional Putera Harapan Purwokerto.

Aplikasi Quizizz mampu menyesuaikan model kuis yang dibuat dengan bahan pengajaran online bahasa Mandarin dengan menyediakan fasilitas untuk merancang model kuis secara bebas. Laman Quizizz dapat diakses melalui alamat https://quizizz.com, guru terlebih dahulu mendaftar pada laman tersebut untuk mendapatkan akun dan selanjutnya dapat merancang model kuis yang diinginkan. Model kuis yang tersedia pada aplikasi Quizizz berupa pilihan ganda (multiple choice), checkbox $(\mathrm{V})$, mengisi kalimat rumpang/jawaban pendek (fill in the blank), angket (poll). Selain itu, kita juga dapat menambahkan media berupa gambar, video atau audio pada setiap pertanyaan maupun jawaban. 


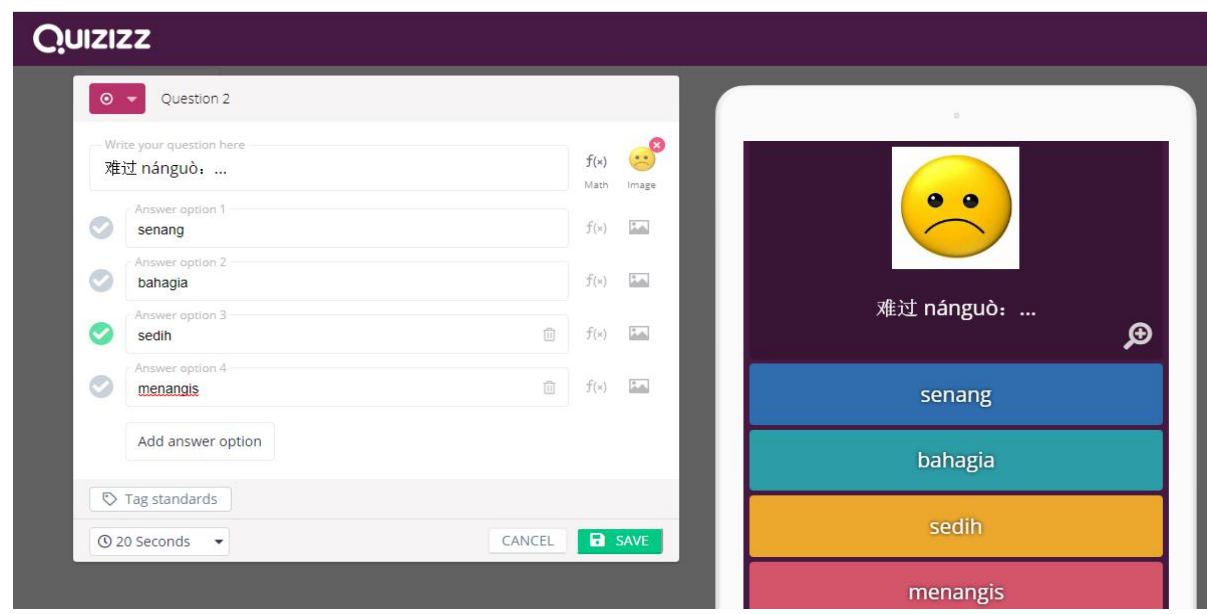

Gambar 1. Merancang kuis pada Quizizz dengan media gambar pada soal

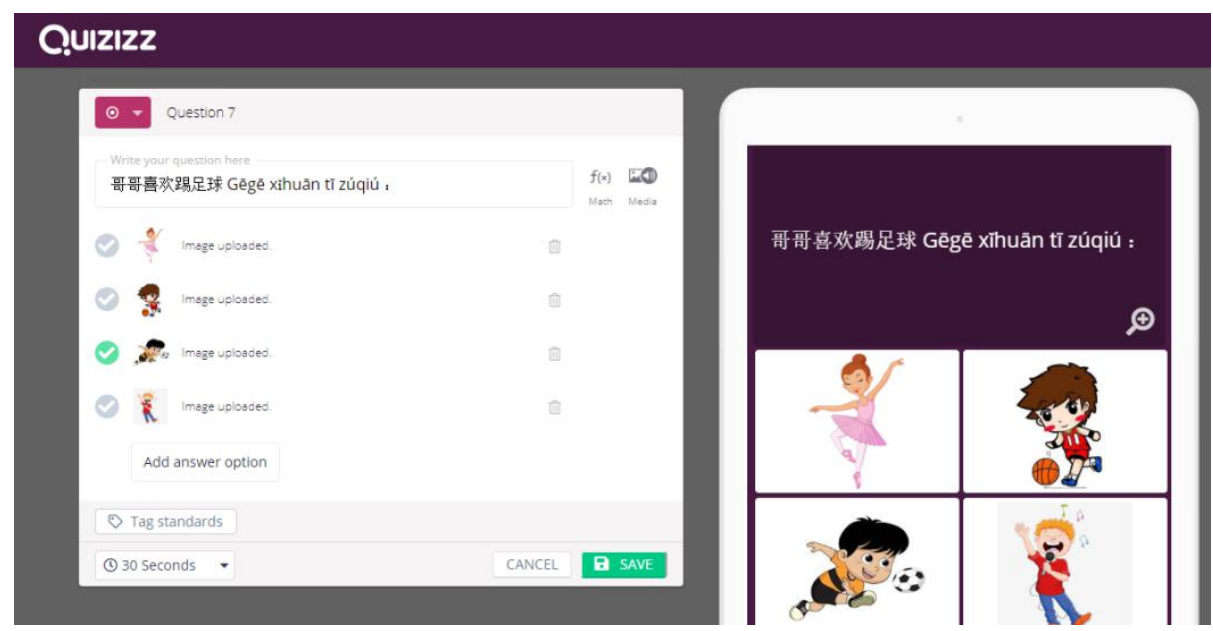

Gambar 2. Merancang kuis pada Quizizz dengan media gambar pada pilihan jawaban

Dalam satu paket kuis, guru bisa memberikan berbagai macam bentuk soal, yaitu berupa pilihan ganda, jawaban singkat, dan pilihan checkbox di mana siswa bisa memilih lebih dari satu jawaban benar. Jika kuis telah selesai dirancang maka simpanlah kuis tersebut, secara otmatis laman Quizizz akan memberikan kode yang dapat dibagikan kepada para siswa, guru juga dapat mengatur batas waktu penyelenggaraan kuis. 


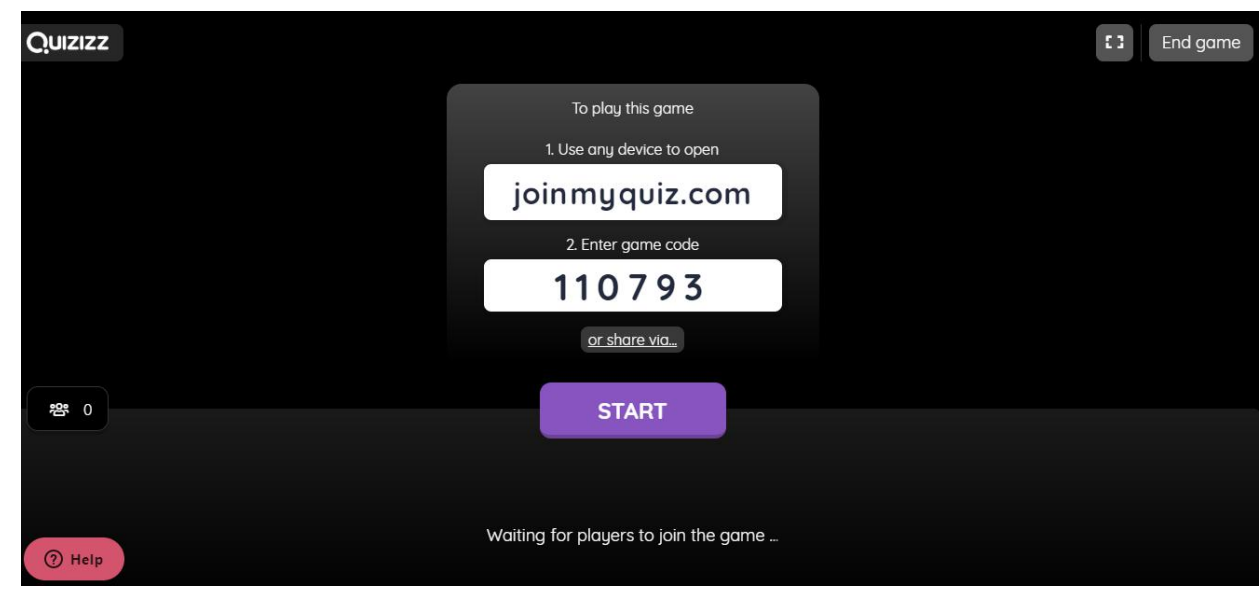

Gambar 3. Kode megkuti Quizizz

Keunggulan lainnya dari aplikasi Quizizz adalah kita dapat menghubungkannya langsung dengan layanan Google Classroom, sehingga semakin memudahkan guru dan murid dalam melakukan kegiatan belajar mengajar sistem daring seperti saat ini.

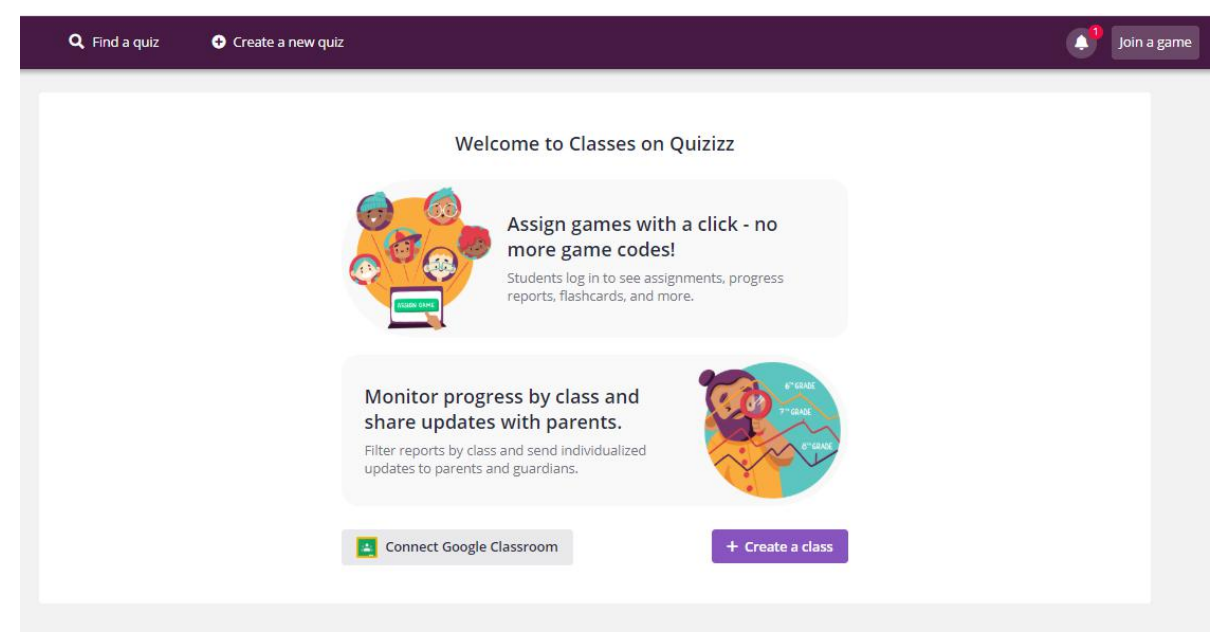

Gambar 4. Menghubungkan Quizizz denan Google Classroom

Hasil penilaian kuis secara otomatis akan terakumulasi dalam bentuk spreadsheet dengan format excel yang dapat diunduh langsung oleh para guru. Selain itu Quizizz juga menyediakan fitur untuk membagikan hasil nilai tersebut kepada para orang tua murid dengan mengirimkannya ke alamat email orang tua setiap murid secara otomatis. Hal ini tentu saja sangat berguna bagi para orangtua untuk memantau perkembangan hasil belajar anaknya. 


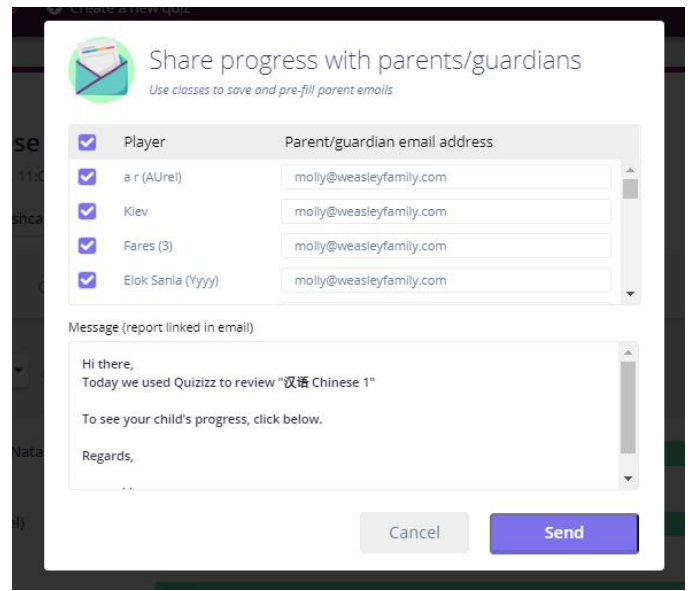

Gambar 5. Fitur share progress with parents

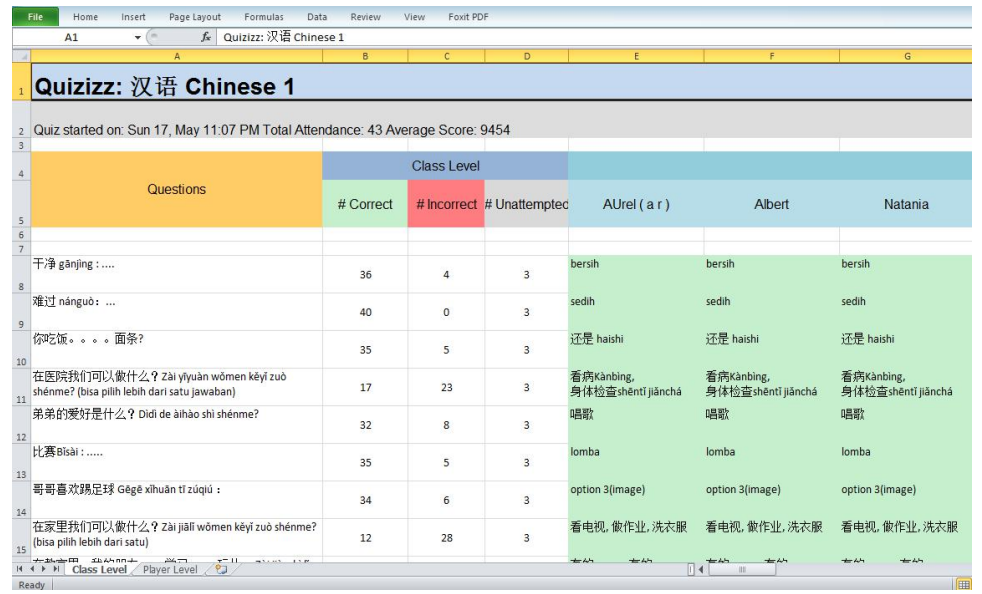

Gambar 6. Hasil perolehan kuis dalam bentuk spreadsheets

Pada gambar 5 terdapat pilihan untuk membagi hasil perolehan nilai para murid kepada orang tua melalui email. Fitur ini dapat digunakan dengan mudah dan cepat dengan menekan kolom centang biru dari daftar nama murid yang ada. Selanjutnya pada gambar 6 terdapat hasil perolehan kuis yang sudah terakumulasi dalam bentuk tabel dengan format excel. Fitur ini dapat memudahkan para guru ketika memasukkan nilai hasil kuis para murid.

Implementasi E-learning aplikasi Quizizz difokuskan untuk meningkatkan hasil pembelajaran bahasa Mandarin bagi siswa. Observasi terhadap para murid dilakukan selama penelitian berlangsung. Sesi kuis online dengan aplikasi Quizizz dilaksanakan selama masa pendemi Covid-19, para murid mengakses kuis online pada aplikasi Quizizz di rumah masing-masing tentunya di bawah bimbingan orang tua. Kuis online dilaksanakan setiap 2 minggu sekali setelah menyelesaikan materi pada satu bab.

Implementasi aplikasi Quizizz berupa E-learning yang digunakan sebagai media pembelajaran berbasis permainan. Metode pembelajaran daring menyebabkan kurang terkontrolnya proses pembelajaran, berbeda dengan pebelajaran tatap muka langsung di mana guru dapat secara langsung memantau proses belajar siswanya. Dengan Quizizz guru secara real-time dapat memberikan latihan soal kepada para murid, atau menggunakan kuis online sebagai PR ataupun tugas mandiri. 


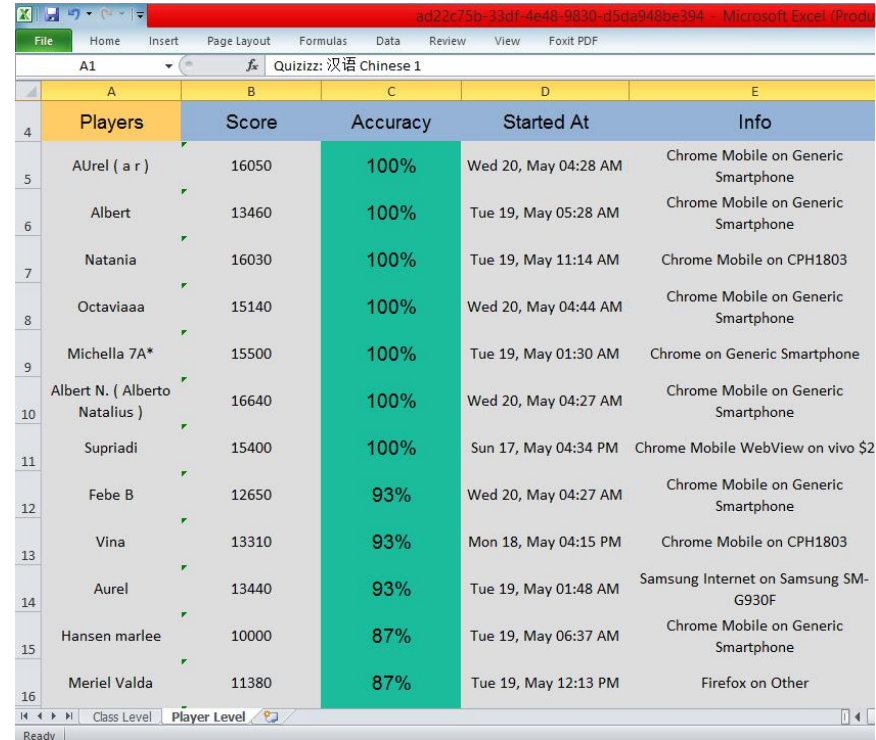

Gambar 6. Nilai siswa dari kuis online Quizizz

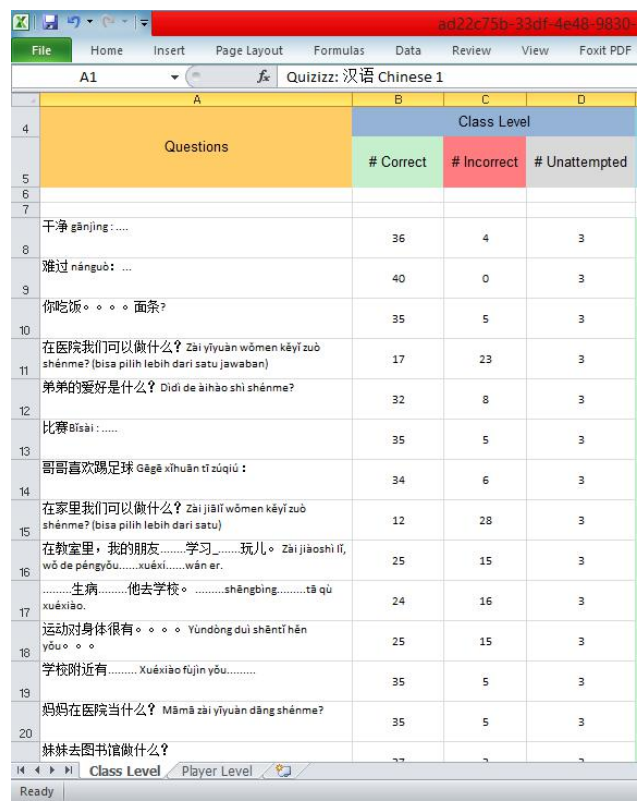

Gambar 7. Rekapitulasi jawaban para siswa

Gambar 6 dan 7 merupakan hasil akumulasi perolehan nilai para siswa setelah mengerjakan kuis online pada Quizizz, secara otomatis data dicatat dalam bentuk spreadsheet pada Microsoft excel yang dapat diunduh oleh para guru. Pada gambar 6 terdapat perolehan nilai yang tercatat secara otomatis, guru memiliki kendali dalam implementasi Quizizz sebagai media evaluasi penilaian digital. Selanjutnya pada gambar 7 terdapat rekapitulasi jawaban dari para murid, dari semua pertanyaan yang diberikan akan tercatat jumlah jawaban benar dan jawaban salah. Misalnya pada pertanyaan “在家里我们 可以做什么? Zài jiālǐ wǒmen kěyǐ zuò shénme?" tercatat 12 murid menjawab benar dan 28 murid menjawab salah, pertanyaan ini merupakan pertanyaan dengan jumlah murid 
menjawab salah terbanyak. Setelah mengetahuinya maka guru dapat melakukan pemantapan materi bagi para murid yang membahas pertanyaan tersebut pada pertemuan berikutnya. Fitur rekapitulasi otomatis ini dapat mempermudah guru mengetahui sejauh mana para siswa memahami bahan ajar yang diajarkan melalui perolehan jawaban siswa pada aplikasi Quizizz.

\section{Hasil Implementasi Aplikasi Quizizz}

Aplikasi Quizizz dapat diakses melalui laptop maupun handphone setiap HP siswa, selain terdapat fitur canggih pengaplikasian Quizizz juga mudah serta dilengkapi dengan setelan warna, gambar dan musik yang menarik. Dari fitur-fitur yang tersedia, pengajar dapat memantau hasil evaluasi murid didiknya dengan sangat efektif,cepat, dan akurat; pengajar dapat menentukan dengan baik metode pengajaran yang paling tepat bagi peserta didik guna meningkatkan penguasan bahasa Mandarin di sekolah Puhua. Koordinasi di dalam WhatsUp Grup Kelas antara peneliti, pengajar, dan para siswa SMP/SMA 3 Bahasa Putera Harapan Purwokerto sangat memudahkan pemantauan hasil belajar yang diterapkan pada aplikasi Quizizz.

Belajar menggunakan aplikasi Quizizz memberikan manfaat yang sangat besar bagi pembelajaran bahasa Mandarin di Sekolah Nasional 3 Bahasa Putera Harapan Purwokerto. Selaian dapat memantau penguasaan bahasa Mandarin siswa didik, juga dapat meningkatkan pemahaman siswa dalam penguasaan bahasa Mandarin. Aplikasi Quizizz yang mudah dan menarik juga membuat motivasi belajar siswa didik meningkat. Waktu pelaksanan yang bisa diatur sesuai kebutuhan juga sangat memungkinkan siswa bisa mengerjakan soal-soal latihan Quizizz dengan leluasa, sehingga capaian tugas bisa $100 \%$ terkumpul sesuai dengan target.

Pemanfaatan aplikasi Quizizz juga sangat dirasakan para pengajar bahasa Mandarin yang dikenal rumit yang kemudian bisa diajarkan dengan menyenangkan berkat penggunaan aplikasi Quizizz, hal ini sangat cocok diterapkan bagi pembelajar pemula. Pemantauan hasil belajar siswa pun dapat dilakukan dengan mudah karena perolehan nilai sudah tercatat otomatis dan dapat langsung diunduh. Dengan terpantaunya hasil belajar murid guru dapat membuat rencana pembelajaran yang lebih tepat sasaran. Koordinasi dengan orang tua murid pun sudah difasilitasi langsung dari aplikasi Quizizz dengan adanya fitur "share progress with parents".

\section{SIMPULAN}

Berdasarkan dari hasil penelitian dan pembahasan dalam penelitian ini dapat disimpulkan bahwa: 1) Implementasi aplikasi Quizizz selama pembelajaran daring sangat tepat sebagai media E-learning pembelajaran bahasa Mandarin karena membuat kegiatan pembelajaran menjadi interaktif, mudah, menyenangkan dan membantu siswa untuk memahami bahasa Mandarin, 2) Penggunaan aplikasi Quizizz dapat memudahkan guru serta orang tua dalam memantau hasil belajar murid, 3) Media pembelajaran berbasis permainan dengan aplikasi Quizizz sangat tepat diterapkan bagi pembelajar pemula bahasa Mandarin. 


\section{DAFTAR PUSTAKA}

[1] Arsyad, Azhar. 2013. Media Pembelajaran. Jakarta: PT. RajaGrafindo Persada.

[2] Darmaningrat, Eko Wahyu. 2018. Pemanfaatan Aplikasi Digital Learning Quizizz Untuk Pembelajaran Pengayaan di Sekolah Menengah Kota Surabaya. Sesindo : Seminar Nasional Sistem Informasi Indonesia.

[3] Kabalmay. 2002. Designing Qualitative Research. London: Sage Publication.

[4] Nurseto, Tejo. 2011. Membuat Media Pembelajaran yang Menarik. Ekonomi Dan Pendidikan, Volume $8 \mathrm{~N}, 19-35$.

[5] Purba, Leony Sanga. 2019. Peningkatan Konsentrasi Belajar Mahasiswa Melalui Pemanfaatan Evaluasi Pembelajaran Quizizz Pada Mata Kuliah Kimia Fisika I. JDP. Vol.12 No.1, 29-39.

[6] Roriarti, Fitri \& Anisa Yunita. 2017. TIK Untuk AUD: Penggunaan Platform "Quizizz!" Dalam Menumbuhkan Jiwa Kompetitif dan Kolaboratif Anak. Pendagogi : Jurnal Anak Usia Dini dan Pendidikan Anak Usia Dini. Vol.3 No.b.

[7] Sudaryanto. 1993. Metode dan Aneka Teknis Analisis Bahasa. Duta Wacana University Press.

[8] Sutirna. (2018). Peran Teknologi Informasi dalam Mendukung Stabilitas Nasional. Seminar Nasional Semnas Ristek. (pp. 269-276).

[9] Suo Yan Mei. 2018. Implementing Quizizz as Game Based Learning in the Arabic Classroom. Journal of Social Science Education and Research, 208-212. 